\title{
Estimation of lowland river cross-section changes for different soils
}

\author{
JANUSZ URBAŃSKI ${ }^{1}$, RYSZARD OLESZCZUK ${ }^{1}$, ANDRZEJ BRANDYK ${ }^{2}$, \\ EWELINA ZAJAC ${ }^{3}$ \\ ${ }^{1}$ Faculty of Civil and Environmental Engineering, Warsaw University of Life Sciences - SGGW, \\ Poland \\ ${ }^{2}$ Water Centre Laboratory, Faculty of Civil and Environmental Engineering, Warsaw University of Life \\ Sciences - SGGW, Poland \\ ${ }^{3}$ Faculty of Environmental Engineering and Land Surveying, University of Agriculture in Krakow, \\ Poland
}

\begin{abstract}
Estimation of lowland river cross-section changes for different soils. This paper involves a comparative analysis of cross-sectional changes at selected reaches of a lowland river, flowing through the areas of mineral and organic soils. The comparisons were made at the background of design and execution assumptions from the period 1967-1971. Main processes, responsible for the observed changes of riverbeds in mineral soils (silting, conservation works) and organic soils (subsidence, disappearance of the peat deposit), were identified. In case of organic soils, the decrease of cross-sectional area by approximately from 30 to $60 \%$ was estimated in comparison to the original project assumptions, and the subsidence of river banks reached even $0.5 \mathrm{~m}$ in relation to the level determined in 1967 . In the area of mineral soils, more considerable variability of cross-sectional area was noted along with minor changes of river banks elevation, that resulted most likely from the performed maintenance works.
\end{abstract}

Key words: lowland river, regulation of the river, sub-irrigation systems, organic and mineral soils

\section{INTRODUCTION}

Riverbeds are subject to continuous transformation. It mainly results from natural hydrological processes, e.g. sea- sonal variation of river flow and sediment transport, but also anthropogenic activities, such as regulation and conservation works. Many lowland rivers underwent those works, especially from 1960 to 1980 , in order to adjust their beds to the demands of drainage-irrigation systems, whose function was to develop proper soil moisture conditions in river valleys. Those rivers used to serve as receivers of drainage water or became the source of water for sub-irrigation systems. Their beds were exposed to natural processes of silting either sedimentation already for decades, becoming shallower and overgrown with vegetation, that incurred changes of their cross-sectional parameters in reference to design and execution assumptions. Those changes may be also attributable to temporal conservation works.

The above-mentioned transformation of riverbeds is typical for the areas of mineral soils, that the lowland rivers flow through. However, in the case of valleys built of organic soils, except for the above-mentioned processes, the subsidence and disappearance of soils 
should be taken into account due to peat shrinkage and compaction as well as organic matter mineralization (Brandyk 2011, Querner et al. 2012, Ilnicki and Szajdak 2016, Grzywna 2017, Lipka et al. 2017, Oleszczuk et al. 2017).

The aim of this paper is to analyse the cross-sections' geometry changes of the lowland river, regulated in the period 1967-1971, flowing through the areas of mineral and organic soils.

\section{MATERIAL AND METHODS}

The Mała river is situated in Piaseczno district, flowing across Góra Kalwaria and Konstancin Jeziorna communities (Mazovia Province - central part of Poland). It forms the right-side tributary of the Jeziorka river near the town of Konstancin-Jeziorna. It's flow is directed generally from south to north, while the length reaches $19.7 \mathrm{~km}$ with the source areas situated in the vicinity of Krzaki Czaplinkowskie (Góra Kalwaria community). The surface of the Mała catchment is estimated to be $72.8 \mathrm{~km}^{2}$ (Lenartowicz 2007) which is a lowland one, typical for the central part of Poland. Two reaches of the valley, being considered herein, involve a very flat area, where the first reach is built of peat soils and the second one of sand deposits on both banks of the river (Kaca 1981, Brandyk 1990, Bujakowski et al. 2014). In the neighborhood of Solec village, the Mała river flows into two main channels, that were constructed between 1941-1943. The target design of sub-irrigation system for surroundings areas so-called the Solec site was being completed from 1966 to 1967 and afterwards the Mała river was des- ignated as a source of water for irrigation of there-existing peatlands (Brożek 1967, Tkaczewski 1970). In 1967-1971 the project of sub-irrigation system finally came into realization phase.

The first river channel became an irrigation ditch $\mathrm{A}$ and the second one was treated as the main bed of the Mała river (Fig. 1) that served both for irrigation and drainage of surrounding lands. The parameters determined in 1967 for the design cross section of the Mała river were as follows: the width of the bottom 1.5-2.0 m, the depth $2.0-2.5 \mathrm{~m}$ and the slope of the banks $1: 1.5$. With respect to the preservation of those values, the Mała river is currently maintained through conservation works executed by water community in the city of Piaseczno. The last maintenance works were carried out in July-August 2012, including: mowing and removing plants from the river, conservation and cleaning of the bottom, and disposal of existing beaver dams. Nowadays, the analyzed reaches of the Mała river, and the surroundings of the river belong to the Chojnowski Regional Park (it is a part of Mazovia Regional Parks) and it is also the area of Natura 2000 PHL 140055. Agricultural use (meadows and pastures) is present mostly on the left side of the river, while on the right side abandoned grasslands exist in a wide extent.

Basing on the project of sub-irrigation system from 1967, eight archival cross-sections were taken into account.

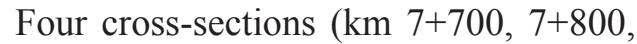
$7+900,8+000)$ of the Mała river were utilized to study cross-sectional geometry changes in the areas of organic soils. However, another four cross-sections $(\mathrm{km} \mathrm{8+900,9+000,9+100,9+200)} \mathrm{were}$ selected at the reach flowing through the 


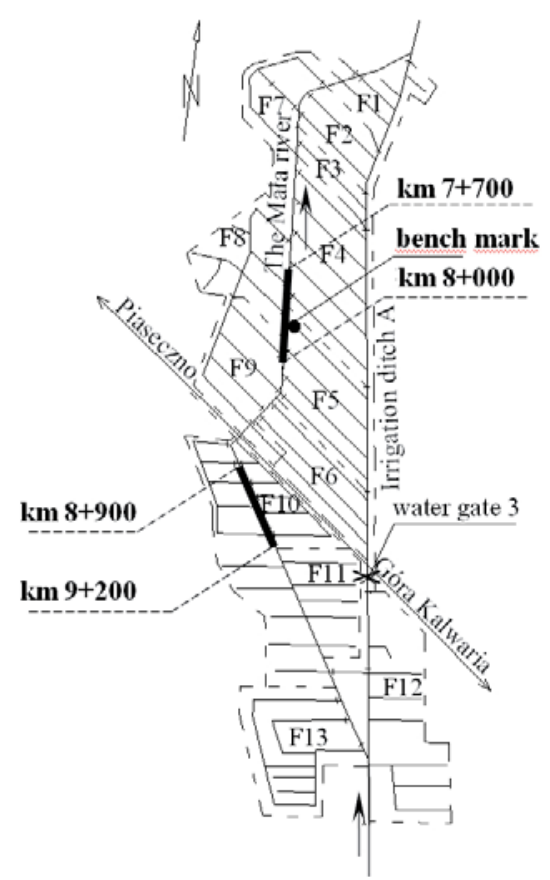

$$
\begin{aligned}
\text { F2 - border and number of the quarter } \\
+ \text { - } \\
\times \text { - water gates } \\
\text { - water gate } 3 \\
\text { - bench mark } 100.60 \mathrm{~m} \text { a.s.1. } \\
\text { - the analyzed reaches of the Mała river: } \\
\quad(\mathrm{km} 7+700-8+000) \text { in } 2013 \\
\quad(\mathrm{~km} 8+900-9+200) \text { in } 2017
\end{aligned}
$$

FIGURE 1. The scheme of the sub-irrigation system at Solec site (Kaca 1981) including analysed reach of the Mała river

area of mineral soils. On 27 August 2013 field measurements of four cross-sections, located in the area of organic soils, were performed. However, on 29 August 2017 the remaining four cross-sections, that is in mineral soils, were surveyed in order to compare the originally designed (1967) and present stage (2013) of the analyzed reaches of the river. Geographical coordinates of all points in cross-sections were estimated by land surveying method and the known values of reference altitude point (100.60 $\mathrm{m}$ a.s.1.) in the closest location (Fig. 1).

According to the previous considerations, the catchment of the Mała river near Solec village embraces two types of soil deposits: the top soils are mainly organic - moorsh and peat layers (reed-sedge) with the degree of decomposition H6-H7 while the bottom of the river lies on sandy deposits (Kaca 1981, Brandyk 1990). In order to estimate the actual depth of each type of soils along the considered four cross-sections on the left bank, the depth of the peat deposit was examined using hand drill (on right bank of the river some organic and mineral materials after conservation works were accumulated).

\section{RESULTS}

The original, designed (1967) and measured cross-sectional areas at the analyzed reaches of the Mała river: $\mathrm{km} \mathrm{7+700-8+000} \mathrm{(August} \mathrm{2013)} \mathrm{and}$ $\mathrm{km} \mathrm{8+900-9+200} \mathrm{(August} \mathrm{2017)} \mathrm{were}$ presented in Figures 2 and 3. It can be observed, that they have been subject to major transformation in comparison to original project assumptions, which 
were finally put into operation in 1971 . There were following, basic parameters distinguished in the project of 1967: the slope of the banks $1: 1.5$, bottom width $1.4 \mathrm{~m}$ and average depth from 1.6 to $2.0 \mathrm{~m}$ (Brożek 1967, Tkaczewski 1970). At the river reach, that flows across the peat deposit of a thickness from 0.85 to
$1.10 \mathrm{~m}$ (Fig. 2), the banks subsidence was noted after 46 year period (1967-2013) on account of organic matter mineralization, which is shown by the measurements from 2013. It is particularly visible on the left river bank, at the $\mathrm{km} \mathrm{7+800} \mathrm{of} \mathrm{cross-section,} \mathrm{where} \mathrm{the}$ subsidence reached $0.45 \mathrm{~m}$ (Fig. 2b).
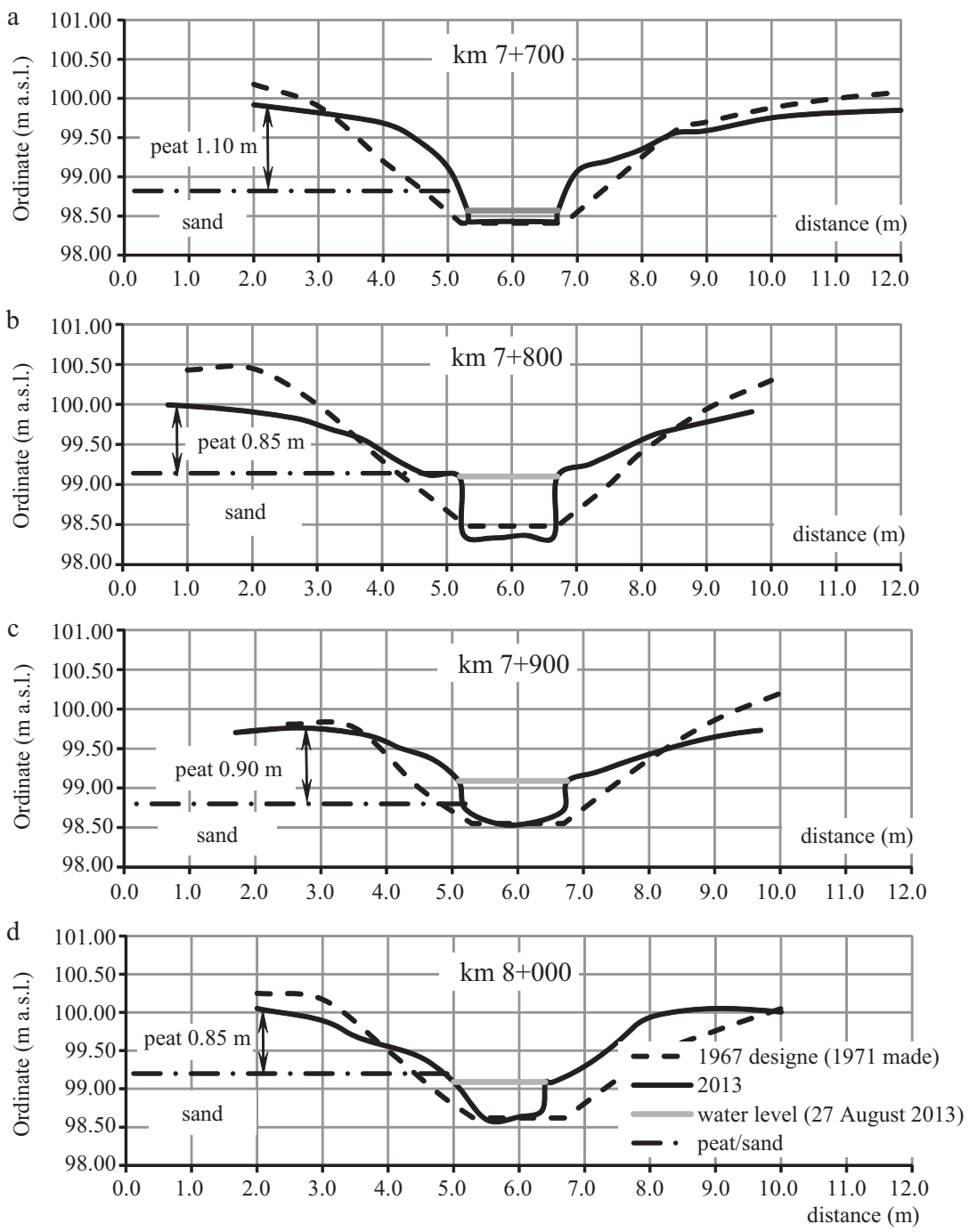

FIGURE 2. The cross-sections of the Mała river: (a) km 7+700, (b) km 7+800, (c) km 7+900, (d) km $8+000$ at the river reach covered by organic soils 
The changes of the right bank elevation were considerably smaller (Tables 1,2), related to the collection of the soil material that had been previously removed from the bottom during temporal maintenance works. A particular attention should be paid to the variability of bank slopes at the analyzed cross-sections, that may be caused by a palisade for stabilizing the bottom and the banks at their base.

Slightly different character of the cross-sectional transformation was observed for the second river reach $(\mathrm{km}$ $8+900-9+200$, Fig. 3) that is situated within mineral soils area. The bottom and banks' elevation recorded in 2017 was not significantly different from the project
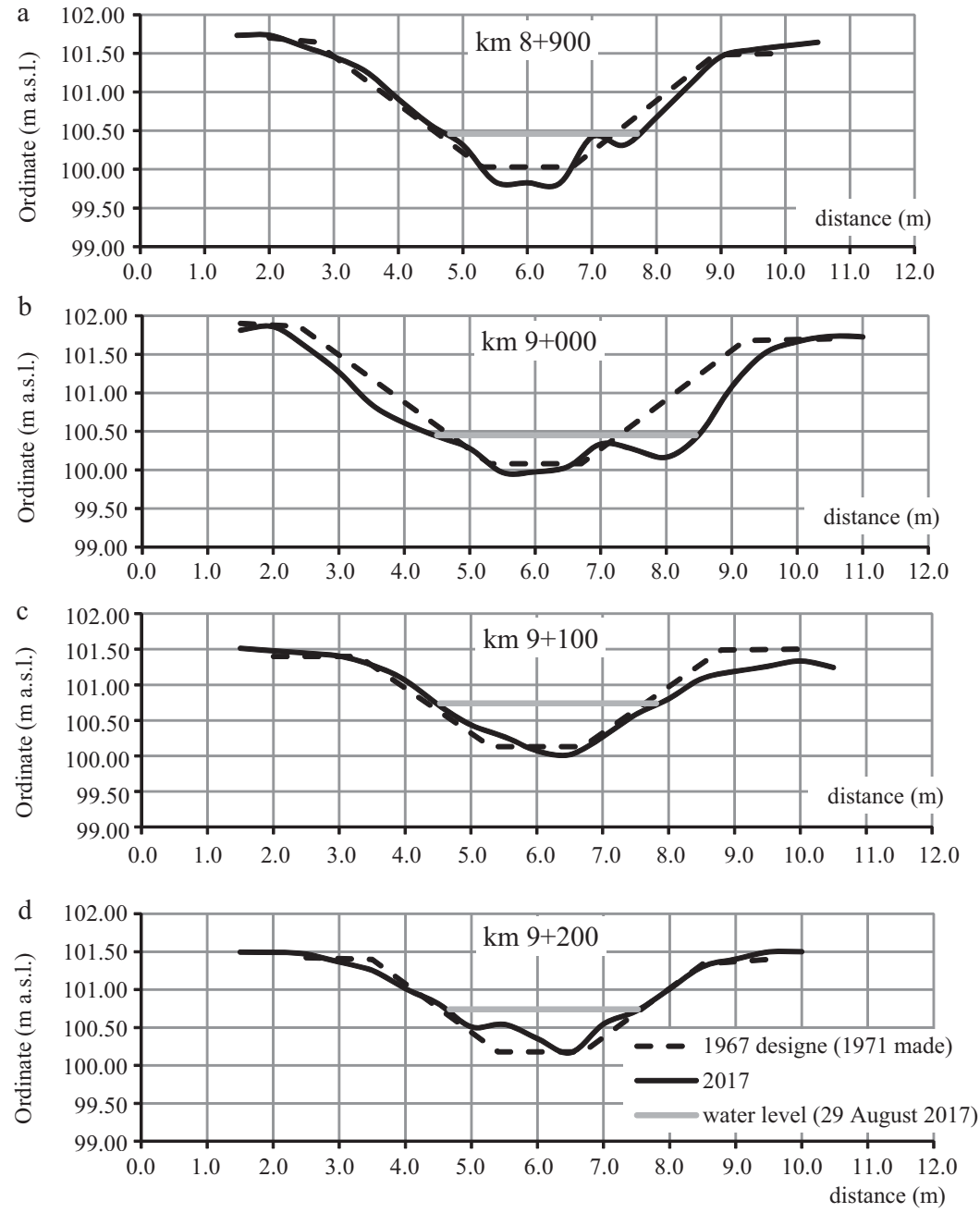

FIGURE 3. The cross-sections of the Mała river: (a) km 8+900, (b) km 9+000, (c) km 9+100, (d) km $9+200$ at the river reach covered by mineral soils 
TABLE 1. The values of ordinates of both bank the Mała river in analyzed cross-sections with the ratio of surface subsidence of banks in analyzed years 1967-2013 for organic soils

\begin{tabular}{|c|c|c|c|c|c|}
\hline Year & Kilometre (cross-section) & $7+700(\mathrm{a})$ & $7+800(\mathrm{~b})$ & $7+900(\mathrm{c})$ & $8+000(\mathrm{~d})$ \\
\hline 2013 & left bank (m a.s.1.) & 99.92 & 99.99 & 99.70 & 100.05 \\
\hline 1967 & left bank (m a.s.1.) & 100.18 & 100.49 & 99.81 & 100.25 \\
\hline Difference $2013-1967(\mathrm{~m})$ & -0.26 & -0.50 & -0.11 & -0.20 \\
\hline 2013 & right bank (m a.s.1.) & 99.85 & 99.91 & 99.73 & 100.01 \\
\hline 1967 & right bank (m a.s.1.) & 100.08 & 100.30 & 100.20 & 100.05 \\
\hline \multicolumn{2}{|r|}{ Difference 2013-1967 (m) } & -0.23 & -0.39 & -0.47 & -0.04 \\
\hline
\end{tabular}

TABLE 2. The values of ordinates of both bank the Mała river in analyzed cross-sections with the ratio of surface subsidence of banks in analyzed years 1967-2013 for mineral soils

\begin{tabular}{|l|c|c|c|c|c|}
\hline Year & Kilometre (cross-section) & $8+900(\mathrm{a})$ & $9+000(\mathrm{~b})$ & $9+100(\mathrm{c})$ & $9+200(\mathrm{~d})$ \\
\hline 2017 & left bank (m a.s.1.) & 101.73 & 101.86 & 101.51 & 101.49 \\
\hline 1967 & left bank (m a.s.1.) & 101.65 & 101.86 & 101.40 & 101.40 \\
\hline Difference & $2017-1967(\mathrm{~m})$ & 0.08 & 0.00 & 0.11 & 0.09 \\
\hline 2017 & right bank (m a.s.1.) & 101.64 & 101.75 & 101.34 & 101.50 \\
\hline 1967 & right bank (m a.s.1.) & 101.48 & 101.68 & 101.49 & 101.34 \\
\hline \multicolumn{2}{|l|}{ Difference 2017-1967 (m) } & 0.16 & 0.07 & -0.15 & 0.16 \\
\hline
\end{tabular}

TABLE 3. The ordinate values of bottom of the river in selected cross-sections in 1967 and 2013 years on the area of organic soils

\begin{tabular}{|l|c|c|c|c|}
\hline Kilometre (cross-section) & $7+700(\mathrm{a})$ & $7+800(\mathrm{~b})$ & $7+900(\mathrm{c})$ & $8+000(\mathrm{~d})$ \\
\hline 2013 & 98.43 & 98.33 & 98.55 & 98.60 \\
\hline 1967 & 98.41 & 98.48 & 98.55 & 98.62 \\
\hline Difference 2013-1967 (m) & 0.02 & -0.15 & 0.00 & -0.02 \\
\hline
\end{tabular}

TABLE 4. The ordinate values of bottom of the river in selected cross-sections in 1967 and 2013 years on the area of mineral soils

\begin{tabular}{|l|c|c|c|c|}
\hline Kilometre (cross-section) & $8+900(\mathrm{a})$ & $9+000(\mathrm{~b})$ & $9+100(\mathrm{c})$ & $9+200(\mathrm{~d})$ \\
\hline 2017 & 99.83 & 99.97 & 100.02 & 100.18 \\
\hline 1967 & 100.03 & 100.08 & 100.13 & 100.18 \\
\hline Difference 2017-1967 (m) & -0.20 & -0.11 & -0.11 & 0.00 \\
\hline
\end{tabular}


assumptions (established in 1967), that were subject to final realization in 1971 . For the three analyzed cross-sectional areas in $\mathrm{km}: 8+900,9+000,9+100$ the bottom was lowered by $0.11-0.20 \mathrm{~m}$ (Table 4), and the banks elevation was noticeably higher at most of the sections (Table 2). It can be attributable to periodical maintenance works in the riverbed, that involved removal of the bottom and banks material and placing it on the riverside.

The next stage of the research involved the influence of: on-going sub- sidence, mineralization of organic matter as well as maintenance works in the riverbed on flow field values $F$ for both river reaches (Figs. 3 and 4). Those values $(F)$ were presented in the form of a relationship with water level ordinates. In case of all analyzed cross-sections within the first reach of the river (km 7+700-8+000) the flow filed $F$ decreased and the reduction degree $\Delta F$ is most frequently from 30 to $40 \%$ in comparison to assumptions of the project from 1967 (Fig. 4b).
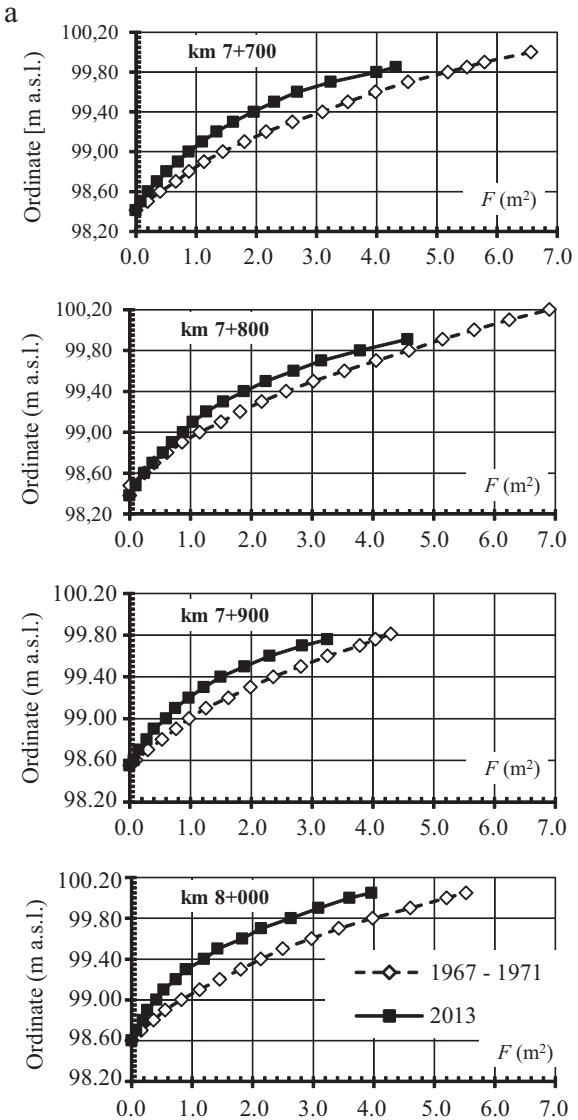

b
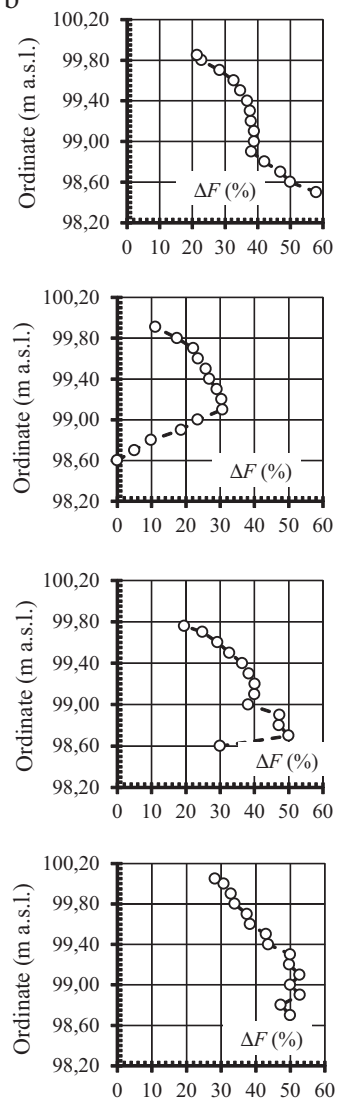

FIGURE 4. The changes of cross-sectional area $F$ : (a) at different water levels in 1971 and 2103 respectively, (b) proportional reduction of cross-sectional area $\Delta F$ in 2013 in comparison with 1971 in the river reach covered by organic soils 
In the second river reach, that is located in the area of mineral soils $(\mathrm{km}$ $8+900-9+200)$, there was a more noticeable character of the geometry changes. In case of the cross-sections located at $\mathrm{km} 8+900$ and 9+100 there was a decrease of the flow field, however, those changes are minor and range from 0 to $11 \%$. In the cross-section situated at $\mathrm{km}$ $9+200$ there was also the decreasing of $F$ field, that at a low water depth equaled about $60 \%$, reducing gradually to about $11 \%$ at bankful water. An attention is particularly given to the section at $\mathrm{km}$ $9+000$, where the flow field increased by several dozen percent. This might be the result of different stage and timing of the conservation works, having considerably widen the cross-sectional area (Fig. 3b).

\section{CONCLUSIONS}

1. The observed cross-section changes in the analyzed river reaches have different causes. In the area of mineral a
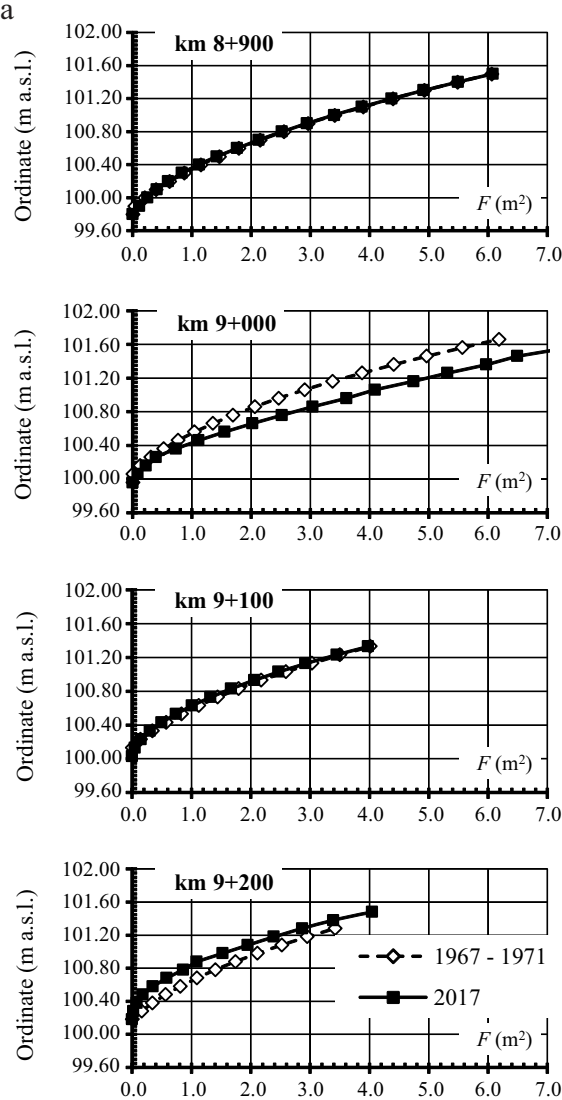

b
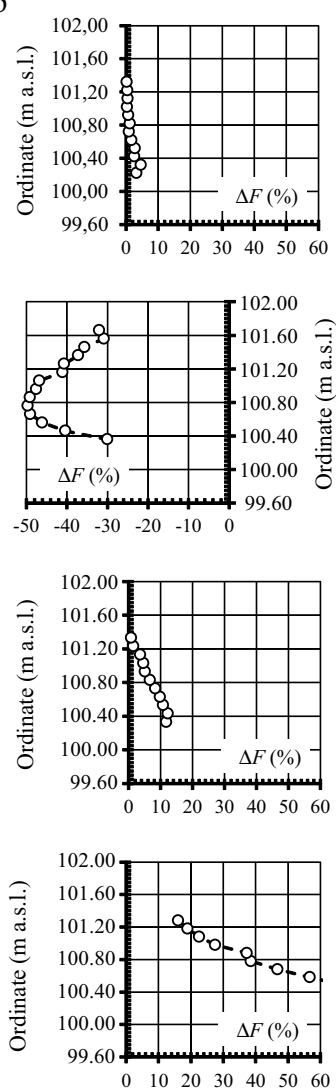

FIGURE 5. The changes of cross-sectional area $F$ : (a) at different water levels in 1971 and 2017 respectively, (b) proportional reduction of cross-sectional area $\Delta F$ in 2017 in comparison with 1971 in the river reach covered by mineral soils 
soils there appeared typical changes of the shape manifested through irregular slope of the banks, variability of the bottom width, that might have been caused mainly by the performed maintenance works. However, the elevation of the banks did not change considerably in comparison to the project assumptions.

2 . In the case of the reach flowing through organic soils area, except for the cross-section geometry changes there was also a considerable lowering of both banks ordinate at about $0.5 \mathrm{~m}$ for the considered period 1967-2013. It was particularly visible on the left river bank, while on the right one the bottom deposits were placed, which were previously removed during conservation works. Their fitting on the right bank probably prevented more advanced subsidence.

3. The transformation of cross-sectional areas exerts an influence on the limitation of a flow field, especially at the reach flowing through the area of organic soils. In that area most noticeable reduction of that parameter occurred, ranging from 40 to $60 \%$. In the area of mineral soils, the reduction was visible in a smaller extent, and is attributable to the on-going maintenance of the river.

\section{REFERENCES}

BRANDYK T. 1990: Podstawy regulowania uwilgotnienia gleb dolinowych [Principles of moisture management for shallow water table soils]. Rozp. Nauk. i Mon. 116. Wydawnictwo SGGW, Warszawa.

BRANDYK A. 2011: Ground water fed system restoration on the area of Przemkowsko - Przecławskie Wetlands. Ann. Warsaw Univ. of Life Sci. - SGGW, Land Reclam. 43 (1): 13-23.
BROŻEK W. 1967: Objaśnienia techniczne do projektu melioracji użytków zielonych obiektu Rzeka Mała Solec [The description of technical Project of land reclamation of the grassland Mała river site]. CBSiPWM, Warszawa.

BUJAKOWSKI F., FALKOWSKI T., WIERZBICKI G., ŻUKOWSKA K. 2014: Using hydrodynamic modelling to assess the impact of the development on hydrogeological conditions in a polygenic river valley marginal zone. Ann. Warsaw Univ. of Life Sci. - SGGW, Land Reclam. 46 (1): 43-55.

GRZYWNA A. 2017: The degree of peatland subsidence resulting from drainage of land. Environ. Earth Sci. 76: \#559. DOI 10.1007/s12665-017-6869-1

ILNICKI P., SZAJDAK L. 2016: Zanikanie torfowisk [Peatlands disappearance]. Wydawnictwo Poznańskiego Towarzystwa Przyjaciół Nauk, Poznań.

KACA E. 1981: Model matematyczny procesu podnoszenia się zwierciadła wody gruntowej przy nawodnieniu podsiąkowym [Mathematical model of rising of ground water level by subirrigation system]. PhD thesis, SGGW-AR, Warszawa [manuscript].

LENARTOWICZ M. 2007: Charakterystyka hydrologiczna Chojnowskiego Parku Krajobrazowego [The hydrological characteristic of the Chojnowski Regional Park] In: M. Falkowski, M. Jeliński, K. Nowicka-Falkowska (Eds.), Chojnowski Park Krajobrazowy Monografia Przyrodniczo Edukacyjna. Zespół Parków Krajobrazowych Mazowieckiego, Chojnowskiego i Brudzeńskiego, Otwock: 29-43.

LIPKA K., ZAJĄC E., HLOTOV V., SIEJKA Z. 2017. Disappearance rate of a peatland in Dublany near Lviv (Ukraine) drained in 19th century. Mires and Peat. 19: 1-15. DOI: 10.19189/MaP.2017.OMB.279

OLESZCZUK R., GĄSOWSKA M., GUZ G., URBAŃSKI J., HEWELKE E. 2017: Wpływ procesów osiadania i zanikania 
gleb organicznych murszowych na profile podłużne rowów odwadniająco-nawadniających [The influence of subsidence and disappearance of organic moorsh soils on longitudinal sub-irrigation ditch profiles]. Acta Sci. Pol. Formatio Circumiectus 16 (3): 3-17.

QUERNER E.P., JANSEN P.C., Van Den AKKER J.J.H., KWAKERNAAK C. 2012: Analysing water level strategies to reduce soil subsidence in Dutch peat meadows. J. Hydrol. 446-447: 59-69.

TKACZEWSKI T. 1970: Ocena oddziaływania urządzeń melioracyjnych na obiekcie Solec pow. Piaseczno [The estimation of land reclamation devices in Solec site, district Piaseczno]. MSc thesis, SGGW, Warszawa [manuscript].

Streszczenie: Analiza zmian przekrojów poprzecznych koryta rzeki nizinnej w różnych ośrodkach gruntowych. W pracy dokonano analizy porównawczej zmian pola przekroju poprzecznego koryta na wybranych odcinkach małej rzeki nizinnej przepływającej przez obszary gleb mineralnych i organicznych. Obiektem badań była rzeka Mała, której całkowita długość wynosi 19,7 km, a powierzchnia zlewni $72,8 \mathrm{~km}^{2}$. Jej koryto zostało poddane regulacji na potrzeby modernizacji systemu nawodnień podsiąkowych na sąsiadującym obiekcie Solec. Po regulacji ta rzeka na wybranych odcinkach stanowiła źródło wody do nawodnień, a na pozostałych pełniła funkcję odbiornika. Porównania zmian geometrii przekrojów poprzecznych koryta oraz jego pola dokonano na tle założeń projektowych regulacji rzeki (1967 r.), zrealizowanych w 1971 roku. Zidentyfikowano główne procesy odpowiedzialne za obserwowane zmiany koryta rzeki na obu analizowanych odcinkach. Na obszarze gleb mineralnych były to głównie procesy zamulania i skutki prac kon- serwacyjnych, a na obszarze gleb organicznych, oprócz wcześniej wymienionych, należy dodatkowo zaliczyć osiadanie brzegów na skutek zanikania złoża torfowego. W przypadku koryta rzeki na obszarze gleb organicznych wykazano zmniejszenie się pola przekrojów poprzecznych najczęściej o ok. $30-40 \%$ w stosunku do założeń projektowych. Obniżenie się brzegów rzeki na tym odcinku wynosiło od 0,04 do $0,50 \mathrm{~m}$. Na obszarze gleb mineralnych zaobserwowano znacznie większe zróżnicowanie zmian kształtu przekrojów koryta przy niewielkich zmianach rzędnych brzegów. W większości analizowanych przekrojów na tym odcinku stwierdzono nieznaczne zmniejszenie się ich pola $(0-11 \%)$, a tylko w jednym z nich nawet do $60 \%$. W przeciwieństwie do obszaru gleb organicznych na odcinku rzeki na obszarze gleb mineralnych zaobserwowano zwiększenie się rzędnych brzegów w granicach $0,08-0,16 \mathrm{~m}$, co głównie wynikało najprawdopodobniej $\mathrm{z}$ efektu prac konserwacyjnych i utrzymaniowych.

Stowa kluczowe: rzeka nizinna, regulacja rzek, systemy nawodnień podsiąkowych, gleby organiczne i mineralne

MS received 10.11.2018

MS accepted 15.12.2018

Authors' address:

Janusz Urbański

Katedra Inżynierii Wodnej

Wydział Budownictwa i Inżynierii Środowiska

Szkoła Główna Gospodarstwa Wiejskiego

w Warszawie

ul. Nowoursynowska 159, 02-776 Warszawa

Poland

e-mail: janusz_urbanski@sggw.pl 